\title{
Effects of Diabetes and Insulin on $\alpha$-amylase Messenger RNA Levels in Rat Parotid Glands
}

\author{
S.K. KIM ${ }^{1,2,3}$, L.M. CUZZORT ${ }^{2}$, R.K. McKEAN ${ }^{2}$, and E.D. ALLEN ${ }^{1}$
}

${ }^{2}$ Research Service, VA Medical Center, Ann Arbor, Michigan 48105; Departments of ${ }^{2}$ Anatomy and Cell Biology, Medical School; and ${ }^{3}$ Biologic and Material Sciences, School of Dentistry, University of Michigan, Ann Arbor

Previous studies have shown that amylase levels are reduced significantly in the pancreas and parotid gland of diabetic rats and that insulin reverses this effect and increases the secretory protein levels. In the pancreas, these changes in amylase protein levels are accompanied by parallel changes in amylase mRNA levels. In the present study, the effects of diabetes and subsequent insulin treatments on contents (per cell) of amylase protein and its mRNA in parotid glands were compared in rats rendered diabetic with an injection of a beta-cell toxin, streptozotocin (STZ). Both amylase protein and its mRNA contents were reduced significantly in diabetic rats, compared with control rats, and this reduction was reversed following insulin injections of diabetic rats. In insulin-injected diabetic rats, amylase protein contents increased before a detectable increase in amylase mRNA levels was seen. The mRNA contents of a non-secretory protein, actin, did not change during diabetogenesis or subsequent insulin treatments. The reductions in parotid contents of amylase and its mRNA in diabetic rats and the reversal of these changes by insulin are similar to those changes that occur in the pancreas under the same conditions. However, the magnitude of these changes in parotid glands was much smaller than in the pancreas, and the effect of insulin on amylase mRNA synthesis was not as immediate as in the latter gland.

\section{J Dent Res 69(8):1500-1504, August, 1990}

\section{Introduction.}

Alpha-amylase is synthesized and secreted primarily by the parotid salivary gland and pancreas. Parotid and pancreatic amylases are encoded by two distinct genes: Amy-1 and Amy2 , respectively (Hagenbuchle $e t a l ., 1980$; Wiebauer $e t$ al. 1985). Although the coding regions of the two genes are $90 \%$ homologous (Hagenbuchle et al., 1980), these genes are associated with different promoters (Hagenbuchle et al., 1981; Young et al., 1981; Osborn et al., 1987). In mice (Young et al., 1981; Schibler et al., 1983) and rats (Sierra et al., 1986), Amy-1 is transcribed from a strong parotid-specific promoter and a weaker one active in the liver, while Amy-2 is associated with a single promoter. Thus, the expression of Amy-1 and Amy-2 genes might be regulated independently.

In the pancreas, levels of amylase and its synthesis are affected by diabetes. In experimental animals rendered diabetic with either alloxan or streptozotocin (STZ), pancreatic amylase levels fall progressively (Christophe et al., 1971; Ben Abdeljlil et al., 1965; Snook, 1968; Söling and Unger, 1972; Korc et al., 1981a, b). The effects of diabetes are specific for the

\footnotetext{
Received for publication September 26, 1989
}

Accepted for publication March 20, 1990

This investigation was supported in part by the Veterans Administration and by USPHS Research Grants DE-08109 from the National Institute of Dental Research and AG-07159 from the National Institute of Aging, National Institutes of Health, Bethesda, MD 20892. individual enzymes, as is the case with dietary regulations of pancreatic enzyme contents and synthesis (Schick et al., 1984a, b). In the pancreas of diabetic rats, amylase activity is markedly decreased, while activities of trypsinogen and chymotrypsinogen are increased (Ben Abdeljlil et al., 1965; Korc et al., 1981b).

The in vivo administration of insulin to diabetic animals reverses this decline in amylase content of the pancreas (Söling and Unger, 1972; Korc et al., 1981a). The rate of amylase synthesis increases, and this increase is also specific for amylase and not for total pancreatic proteins (Söling and Unger, 1972; Korc et al., 1981b). The amylase mRNA level increases with the increase in amylase protein synthesis, while chymotrypsinogen protein and its mRNA slightly decrease (Korc et al., 1981b). These studies indicate a selective effect of insulin on pancreatic amylase gene expression.

The effects of diabetes and insulin on amylase and its mRNA in parotid glands are unclear. In rats rendered diabetic with an injection of alloxan (Anderson and Johnson, 1981; Anderson, 1983), parotid levels of amylase were significantly less than in control rats of comparable ages, and this effect was reversed upon treatment with insulin (Anderson, 1983). On the other hand, Palla et al. (1967) reported that the amylase levels in parotid glands did not change in alloxan-induced diabetic rats. Furthermore, it has been reported that diabetes or subsequent insulin treatments have no significant effect on amylase protein or mRNA levels in parotid glands of the rat (Korc et al., 1981b).

We have examined the changes in levels of amylase protein and its mRNA in parotid glands of rats that were rendered diabetic with STZ and subsequently treated with insulin. The changes in amylase mRNA levels were compared with the levels of mRNA of a non-secretory protein, actin, for determination of whether diabetes and insulin specifically affected this secretory protein messenger in parotid glands.

\section{Materials and methods.}

Rats. - Male Sprague-Dawley rats, obtained from Harlan Sprague-Dawley, Inc. (Indianapolis, IN), were used in this study. These rats were free of viruses and showed negative immunological titers for sialodacryoadenitis (SDA) viruses, which are known to affect the structure and function of salivary glands (Jonas et al., 1969). Rats weighing 200-250 g were given a single intraperitoneal injection of STZ $(6.5 \mathrm{mg} / 100 \mathrm{~g}$ body weight) in $10 \mathrm{mmol} / \mathrm{L}$ citrate buffer, $\mathrm{pH} 4.3$ (Korc et al. 1981b) for induction of diabetes. The concentration of STZ was adjusted so that each rat received about $0.5 \mathrm{~mL}$. Uninjected rats of comparable ages served as controls. A group of diabetic rats was given daily injections of 4 units $/ 100 \mathrm{~g}$ body weight of Lente insulin (Eli Lilly and Co., Indianapolis, IN) 12 days after the STZ injection. Thus, the following groups of rats were studied: D6 and D12 diabetic rats (six or 12 days, respectively, following the injection of STZ) and D12-I1 and D12-I7 (animals receiving insulin injections for one or seven days after being diabetic for 12 days). Parotid glands were 
removed at about the same time of the day (9:00 AM) for all experiments so that the variability in secretory protein contents would be reduced. However, the rats were not fasted, since some diabetic rats did not survive overnight starving.

Serum glucose determinations. - The serum level of glucose was measured with a commercially available assay kit (Sigma, St. Louis, MO). Blood was collected from rats by the tips of their tails being cut off.

Amylase and protein assays. -Parotid amylase was extracted by homogenization of the gland in ice-cold distilled water, and the enzyme level was determined by the method of Bernfeld (1955), with starch used as the substrate. Protein content was determined according to Lowry et al. (1951). Amylase and protein contents were compared on a per-microgram DNA basis as previously described (Kim, 1981; Kim et al., $1980,1981)$. The DNA content was determined by the diphenylamine method of Burton (1956) after extraction of DNA with $0.5 \mathrm{~mol} / \mathrm{L}$ perchloric acid from an aliquot of the glandular homogenate. The homogenization of the gland in ice-cold distilled water or $0.5 \mathrm{~mol} / \mathrm{L}$ perchloric acid did not make significant differences in DNA values (unpublished observations).

RNA extraction. - Total unfractionated RNA was extracted from parotid glands by essentially the same procedures as described by Chirgwin et al. (1979). The homogenizing medium contained guanidinium thiocyanate to inhibit RNase activity. RNA was precipitated with ethanol and acetic acid, dried, dissolved in sterile, diethyl pyrocarbonate-treated water, and kept frozen at $-100^{\circ} \mathrm{C}$ after being divided into aliquots. Individual aliquots of frozen RNA were thawed and used once. Only the RNA samples that showed two sharp ribosomal RNA bands after separation by electrophoresis on agarose gel (Maniatis et al., 1982 ) were used for further studies. The ratio of ${ }^{\mathrm{A}} 260 /$ ${ }^{A} 280$ of the RNA samples ranged from 1.8 to 2.14 , and the DNA contamination was less than $1 \%$.

Northern blots. - RNA samples were denatured with formaldehyde by being heated for $15 \mathrm{~min}$ at $55^{\circ} \mathrm{C}$. After electrophoresis on $2.2 \mathrm{~mol} / \mathrm{L}$ formaldehyde- $1 \%$ agarose gel, the RNA was transferred to nitrocellulose filters (Maniatis et al., 1982). The filter was washed in $3 \mathrm{X}$ SSC (standard sodium citrate: $0.15 \mathrm{~mol} / \mathrm{L}$ sodium chloride and $15 \mathrm{mmol} / \mathrm{L}$ sodium citrate), air-dried, and baked for three to four $\mathrm{h}$ at $80^{\circ} \mathrm{C}$ under vacuum for fixing of the RNA to the filter. After hybridization (described below), autoradiographs were prepared with XO-matic AR film (Kodak, Rochester, NY).

$R N A$ dot blots. - RNA samples were diluted, denatured as described above, and applied to nitrocellulose filters with a Minifold I (Schleicher and Schuell, Keene, $\mathrm{NH}$ ) being used as a guide. The filters were dried and baked as described above. After hybridization, the dots were cut out, and radioactivity was counted in a Beckman scintillation counter (LS 9800).

Probe generation and determination of saturating concentration. - Hybridization was carried out with antisense mRNA riboprobes generated with a commercially available kit following the manufacturer's instructions (Promega Biotech, Madison, WI). For amylase riboprobe generations, the cDNA isolated from $\mathrm{pUC} 9$ vector was inserted into the Pst $\mathrm{I}$ site of pGEM-4Z (Promega). After linearization with restriction enzyme $K p n I$ (BBL, Gaithersburg, MD), riboprobe transcripts were synthesized with the cloned CDNA used as a template in the presence of T7 RNA polymerase (Promega) and cytidine $5^{\prime}-\left[\mathrm{a}-{ }^{32} \mathrm{P}\right]$ triphosphate (Amersham Corp., Arlington Heights, IL). The actin probe was generated similarly, except that the cDNA template in Bluescribe vector was linearized with HindIII (Promega), and transcription was carried out in the presence of T3 RNA polymerase (Boehringer Mannheim Biochemicals, Indianapolis, IN). The cDNA template was digested with DNase I (BRL), and unincorporated label was removed with a Seph- adex G-50 column (Nick columns, Pharmacia, Piscataway, $\mathrm{NJ})$. The specific activities of the probes were 6 and $4 \times 10^{7}$ $\mathrm{cpm} / \mu \mathrm{g}$ RNA for amylase and actin, respectively. The saturating probe concentration was determined by hybridization of nitrocellulose filters containing spots of an equal amount of RNA to increasing concentrations of riboprobe. Hybridization was carried out overnight at $50^{\circ} \mathrm{C}$ with the saturating probe concentration and as described by Maniatis et al. (1982). After hybridization, blots were rinsed three times (one, five, and ten min each) with a solution containing $2 \times$ SSC and $0.1 \%$ SDS (sodium dodecyl sulfate) at room temperature. Blots were further washed two times in a solution of $0.1 \mathrm{x}$ SSC and $0.1 \%$ SDS at $55^{\circ} \mathrm{C}$ for 60 and $30 \mathrm{~min}$.

Statistical analysis. - The statistical significance of differences among mean values was determined by one-way analysis of variance (ANOVA) followed by Duncan's New Multiple Range Test.

\section{Results.}

After a single intraperitoneal injection of STZ, the rats became diabetic, as evidenced by the elevated blood glucose level (Table 1). The serum glucose level elevated to about five times the normal level six to 12 days after the injection (Table 1). In this study, only those rats with the serum glucose level of higher than $27.8 \mathrm{mmol} / \mathrm{L}(500 \mathrm{mg} / \mathrm{dL})$ were used as diabetic rats. The body weights of the STZ-injected rats increased only slightly (about $4.8 \%$ ) in two weeks following the injection (Table 1), as compared with control rats, which gained about $26 \%$ during the same time period.

The insulin injection lowered the serum glucose level (Table 1), although the sugar level fluctuated much more widely in insulin-injected rats than in normal or diabetic rats even after seven daily injections. The body weight increased with insulin injections. After seven days of insulin injection, the weight of the diabetic rats increased by about $28 \%$ of the pre-injection weight. During the three-week period of experiments, the body weight of uninjected rats of a comparable age increased about $150 \mathrm{~g}$. Despite this weight gain, the glandular contents of DNA (per mg tissue), total protein ( $p e r \mu g$ DNA), and amylase (per $\mu \mathrm{g}$ DNA) in these control rats did not change significantly (Table 2).

Parotid contents of DNA and total protein did not change significantly in diabetic rats or in diabetic rats treated with

TABLE 1

BODY WEIGHT AND SERUM GLUCOSE LEVEL IN CONTROL AND DIABETIC RATS

\begin{tabular}{ccc}
\hline \hline Treatment & $\begin{array}{c}\text { Body Weight } \\
(\mathrm{g})\end{array}$ & $\begin{array}{c}\text { Serum Glucose } \\
\text { (mmol/L) }\end{array}$ \\
\hline Control & $242.5 \pm 2.7(9)$ & $6.5 \pm 0.5(9)$ \\
D6 & $251.3 \pm 9.5(4)$ & $31.4^{*} \pm 1.0(4)$ \\
D12 & $248.6 \pm 5.5(7)$ & $29.4^{*} \pm 2.2(4)$ \\
D12-I1 & $276.4^{*} \pm 5.7(7)$ & $18.9 \pm 1.8(4)$ \\
D12-17 & $311.9^{*} \pm 7.7(7)$ & $10.1+2.9(10)$ \\
\hline
\end{tabular}

Values are mean $\pm \mathrm{SEM}$.

The numbers in parentheses denote the number of rats used for each assay.

Control: Body weight at the time of STZ injection.

D6: Six days after streptozotocin injection.

D12: Twelve days after streptozotocin injection.

D12-11: Twelve days after streptozotocin followed by one injection of insulin on day 13.

D12-17: Twelve days after streptozotocin followed by seven daily injections of insulin.

*Indicates the mean values that are significantly different by Duncan's Multiple Range Test $(p \leq 0.05)$ from the other means in the same column. 
TABLE 2

DNA, PROTEIN, AND AMYLASE CONTENTS OF PAROTID GLANDS IN CONTROL RATS

\begin{tabular}{lccc}
\hline \hline $\begin{array}{l}\text { Body* } \\
\text { Weight }(\mathrm{g})\end{array}$ & $\begin{array}{c}\text { DNA } \\
\mu \mathrm{g} / \mathrm{mg} \text { Tissue }\end{array}$ & $\begin{array}{c}\text { Protein } \\
\mu \mathrm{g} / \mu \mathrm{g} \mathrm{DNA}\end{array}$ & $\begin{array}{c}\text { Amylase } \\
\text { Units }^{+} / \mu \mathrm{g} \text { DNA }\end{array}$ \\
\hline $225-275$ & $5.76 \pm 0.28(9)$ & $17.70 \pm 0.99(9)$ & $9.33 \pm 1.18(9)$ \\
$276-325$ & $5.53 \pm 0.94(4)$ & $18.30 \pm 1.11(4)$ & $8.32 \pm 0.56(4)$ \\
$326-375$ & $5.56 \pm 0.44(4)$ & $19.50 \pm 1.76(4)$ & $8.04 \pm 0.41(4)$ \\
\hline
\end{tabular}

Values are mean \pm SEM.

The numbers in parentheses represent numbers of rats used for each assay.

*The three groups represent the body weight ranges at the beginning, middle, and end of the experimental period of three weeks.

+ Units represent $\mathrm{mg}$ of maltose released in three min of incubation at $37^{\circ} \mathrm{C}$

insulin (Table 3). However, amylase contents in parotid glands of six- and 12-day diabetic rats were reduced to about $40 \%$ of the control level (Table 3). Insulin increased parotid amylase contents, which were significantly higher than in diabetic glands and reached levels equal to about $70 \%$ of the pre-STZ level after seven daily injections (Table 3 ).

Corresponding to the reduced amylase contents, the amylase mRNA levels in parotid glands of diabetic rats were also lower than in the control glands. The mRNA contents were reduced to $82 \%$ and $57 \%$ of the control level in six- and 12 -day diabetic rats, respectively (Table 4). Insulin treatments of these diabetic rats increased the amylase mRNA contents. The mRNA level increased to about $87 \%$ of the normal level after seven days of insulin (Table 4). However, the effect of insulin was not immediate: The amylase mRNA content did not increase after one injection of insulin (Table 4, Fig.).

Despite the changes in parotid levels of amylase mRNA in diabetic rats before and after insulin treatments, the molecular size of this mRNA did not change and was the same as that in control glands (Fig.). Also, the level of actin mRNA was

Fig. - Northern blot of total parotid RNA hybridized with ${ }^{32}$ P-labeled antisense riboprobe amylase mRNA. Parotid RNA was obtained from control (Lane 1), six-day (lane 2), and 12-day (lane 3 ) diabetic rats. Lanes 4 and 5 contained parotid RNA from 12-day diabetic rats injected with insulin for one and seven days, respectively. Parotid amylase mRNA from these rats was of the same molecular size. A comparison of lanes 3 and 4 revealed no increase in amylase mRNA in parotid glands after an insulin injection of diabetic rats.
TABLE 3

DNA, PROTEIN, AND AMYLASE CONTENTS IN PAROTID GLANDS OF CONTROL AND DIABETIC RATS

\begin{tabular}{cccc}
\hline \hline & $\begin{array}{c}\text { DNA } \\
\mu \mathrm{g} / \mathrm{mg} \text { Tissue }\end{array}$ & $\begin{array}{c}\text { Protein } \\
\mu \mathrm{g} / \mu \mathrm{g} \mathrm{DNA}\end{array}$ & $\begin{array}{c}\text { Amylase* } \\
\text { Units } \\
\text { DNA } / \mu\end{array}$ \\
\hline Treatment & $5.66 \pm 0.26$ & $18.24 \pm 0.69$ & $8.79 \pm 0.64$ \\
Control (17) & $6.12 \pm 0.68$ & $15.39 \pm 1.13$ & $3.14 \pm 0.67$ \\
D6 (4) & $6.24 \pm 0.42$ & $17.82 \pm 0.82$ & $3.82 \pm 0.91$ \\
D12 (6) & $6.09 \pm 0.42$ & $16.12 \pm 1.72$ & $5.86 \pm 0.61$ \\
D12-I1 (6) & $5.33 \pm 0.38$ & $15.40 \pm 1.24$ & $6.42 \pm 0.72$ \\
D12-I7 (9) & & &
\end{tabular}

Values are mean \pm SEM.

The numbers in parentheses denote the number of rats used for each assay.

Control: Values represent means of all 17 rats listed in Table 2.

D6: Six days after streptozotocin injection.

D12: Twelve days after streptozotocin injection.

D12-I1: Twelve days after streptozotocin followed by one injection of insulin on day 13.

D12-I7: Twelve days after streptozotocin followed by seven daily injections of insulin.

*The mean values are significantly different by Duncan's Multiple Range Test ( $p \leq 0.05)$ among the following groups: Control and D12-17 vs. D6, D12, and D12-I1; D6 vs. D12-Il and D12-I7; D12 vs. D12-I7.

+Units represent $\mathrm{mg}$ of maltose released in three min of incubation at $37^{\circ} \mathrm{C}$.

not affected by either STZ or insulin treatments. The level of this non-secretory protein mRNA in parotid glands of diabetic or insulin-injected rats was not different from that in control rats (Table 4).

\section{Discussion.}

The elevated serum glucose level and retarded weight gains in STZ-injected rats indicated that these rats were diabetic. Also, the parotid acinar cells in these injected rats were filled with lipid granules of different sizes (unpublished observations), as was described for experimentally-induced diabetic rats (Anderson, 1983; Hand and Weiss, 1984).

The parotid content of amylase, on a per-cell (DNA) basis, was reduced in STZ-induced diabetic rats, compared with control rats. Insulin administration reversed the effects of STZinduced diabetes on parotid cell contents of amylase. Thus, the results of this study support the previous findings on the effects of alloxan diabetes and insulin on parotid amylase contents (Anderson and Johnson, 1981; Anderson, 1983).

The parotid contents of DNA and total protein did not change in STZ-induced diabetic rats and were not different from those of control rats, as reported previously in alloxan-induced diabetic rats (Anderson and Johnson, 1981). Anderson (1983) has reported that alloxan diabetes resulted in reductions in glandular contents of DNA, RNA, and protein when comparisons were made with those values in control rats fed "a pelleted bulk diet" to compensate for hyperphagia in the diabetic rats. The rats in the present study were on standard pellet food, and the DNA contents, compared based on the tissue weight, were not significantly different among the various experimental and control groups (Tables 2 and 3).

The STZ-induced diabetes and subsequent insulin treatment had effects on amylase mRNA levels similar to those on amylase protein levels in parotid glands. However, the changes in amylase protein and its mRNA levels did not exactly parallel each other during diabetogenesis or subsequent insulin treatment (Tables 2 and 4). One reason for this discrepancy might be related to fluctuations in parotid contents of amylase protein due to variations in the secretory activity of the gland in dia- 
TABLE 4

QUANTITATION OF AMYLASE AND ACTIN mRNA BY DOT BLOT HYBRIDIZATION

\begin{tabular}{|c|c|c|c|}
\hline Treatment & $\begin{array}{c}\text { Number } \\
\text { of } \\
\text { Rats }\end{array}$ & $\begin{array}{c}\text { Amylase } \\
\text { mRNA } \\
\mathrm{CPM} / \mu \mathrm{g} \text { RNA } \times 10^{-3} \\
\end{array}$ & $\begin{array}{c}\text { Actin } \\
\text { mRNA } \\
\text { CPM/ } / \mu g \text { RNA }\end{array}$ \\
\hline Control & 7 & $40.48 \pm 4.92$ & $0.193 \pm 0.013$ \\
\hline D6 & 5 & $33.14^{+} \pm 6.81$ & $0.227 \pm 0.033$ \\
\hline D12 & 8 & $23.04^{*} \pm 3.45$ & $0.241 \pm 0.027$ \\
\hline D12-I1 & 3 & $15.37^{*} \pm 3.37$ & $0.205 \pm 0.019$ \\
\hline D12-17 & 4 & $35.25^{+} \pm 5.60$ & $0.197 \pm 0.027$ \\
\hline
\end{tabular}

Values are mean \pm SEM.

D6: Six days after streptozotocin injection.

D12: Twelve days after streptozotocin injection.

D12-11: Twelve days after streptozotocin followed by one injection of insulin on day 13.

D12-17: Twelve days after streptozotocin followed by seven daily injections of insulin.

*Indicates the mean values that are significantly different by Duncan's Multiple Range Test $(\mathrm{p} \leq 0.05)$ from the control value.

+Indicates the mean values that are significantly different by Duncan's Multiple Range Test $(p \leq 0.05)$ from the mean of D12-11.

betic or insulin-treated diabetic rats. According to Anderson (1983), as well as our unpublished observations, the food intake increases in diabetic rats. The possibility exists that the lower level of parotid amylase was related to an elevated rate of secretion due to increased mastication associated with hyperphagia in diabetic rats (Anderson, 1983). However, it is unlikely that the level of a secretory protein (amylase) mRNA will be reduced in glands with an increased secretory activity. Furthermore, it has been shown previously that peroxidase levels are increased and DNase is unaffected, while amylase levels are reduced in parotid glands of diabetic rats (Anderson, 1983). The increase in secretory activity is likely to affect the glandular levels of all secretory proteins equally.

The effects of diabetes and insulin on amylase protein and its mRNA in the pancreas and parotid gland appear to be selective for this secretory protein. Even among pancreatic enzymes of diabetic rats, only the amylase activity was markedly decreased, while activities of trypsinogen and chymotrypsinogen were increased (Ben Abdeljlil et al., 1965; Korc et al., 1981a). Insulin appears to have an inverse effect on amylase and chymotrypsinogen mRNA levels (Korc et al., 1981b). Similarly, insulin seems to affect amylase selectively in rat parotid glands as well, as mentioned above (Anderson, 1983). As shown in this study, insulin increased amylase mRNA levels in parotid glands of diabetic rats as in the pancreas. However, neither diabetes nor insulin had any effect on the level of actin mRNA, an mRNA for a non-secretory protein in rat parotid glands.

Thus, diabetes-induced reductions and restorations by insulin of amylase protein and its mRNA in parotid glands were quite similar to the changes that occur in the pancreas. However, the magnitude of these changes was much greater in the pancreas than in parotid glands (Söling and Unger, 1972; Korc et al., 1981b). In the pancreas, amylase mRNA, which is decreased by 100 -fold in rats 13 days after an injection of STZ, increased back to normal after seven daily injections of insulin (Korc et al., 1981b). This difference in the magnitude of depression in amylase mRNA levels in these two digestive glands probably reflects the relative significance of the role that pancreatic amylase plays in converting dietary carbohydrates to absorbable sugars. Suppression of the production of amylase for prevention of this conversion may constitute a natural physiological response to elevated sugar levels in diabetic animals.
Although insulin increases amylase mRNA in parotid glands, the effect of insulin on amylase mRNA synthesis did not appear to be immediate, since these mRNA levels in parotid glands continued to show a decline even one day after insulin treatment. On the other hand, parotid amylase levels were increased a day after insulin injection of diabetic rats, suggesting that insulin exerts its influence on amylase synthesis at the level of translation. It has been shown previously that incubation of parotid tissues with insulin stimulated the incorporation of ${ }^{3} \mathrm{H}$-leucine into total protein and amylase (McPherson and Hales, 1978). Also, insulin stimulated protein synthesis in pancreatic acinar cells in vitro (Korc et al., 1981a; Williams and Goldfine, 1986; Okabayashi et al., 1987), as well as in vivo (Söling and Unger, 1972). The insulin effect of increasing protein synthesis seemed to be rapid (within one to two hours) and occurred without changes in translatable amount of mRNA (Okabayashi et al., 1987), leading to a suggestion that insulin has a short-term translational and a long-term transcriptional effect on protein synthesis.

The exact mechanism by which insulin regulates amylase synthesis in the parotid gland or pancreas is unknown. However, a recent study of an amylase/chloramphenicol acetyltransferase (CAT) hybrid in transgenic mice has shown that insulin regulates amylase synthesis at the level of transcription, rather than by regulating the processing of mRNA or its stability (Osborn et al., 1988). It is unknown whether insulin regulation of amylase synthesis is at the level of gene transcription in parotid glands. Nevertheless, the increased level of amylase mRNA following seven daily injections of insulin in parotid glands of diabetic rats (Table 4) supports the suggestion that insulin exerts its influence at the level of amylase gene transcription. If, indeed, amylase gene expression is regulated by insulin, it may not be surprising that parotid (Amy1) and pancreatic (Amy-2) amylase genes are regulated independently in rats, since these genes are associated with different promoters (Hagenbuchle et al., 1981; Young et al., 1981; Osborn et al., 1987).

\section{Acknowledgments.}

We thank Dr. Miriam H. Meisler, Human Genetics Department, University of Michigan Medical School, for providing us with amylase cDNA, and Virginia W. Hartog, VA Medical Center, Ann Arbor, for her assistance.

\section{REFERENCES}

ANDERSON, L.C. (1983): Effects of Alloxan Diabetes and Insulin in vivo on Parotid Gland, Am J Physiol 245:G431-G437.

ANDERSON, L.C. and JOHNSON, D.A. (1981): Effects of Alloxan Diabetes on Rat Parotid Gland and Saliva, Comp Biochem Physiol B 70:725-730,

BEN ABDELJLIL, A.; PALLA, J.C.; and DESNUELLE, P. (1965): Effect of Insulin on Pancreatic Amylase and Chymotrypsinogen, Biochem Biophys Res Commun 18:71-75.

BERNFELD, P. (1955): Amylases. Alpha and Beta, Meth Enzymol $1: 149-158$.

BURTON, K. (1955): A Study of the Conditions and Mechanism of Diphenylamine Reaction for the Colorimetric Estimation of Deoxyribonucleic Acid, Biochem J 162:315-323.

CHIRGWIN, J.M.; PRYZYBYLA, A.E.; MacDONALD, R.J.; and RUTTER, W.J. (1979): Isolation of Biologically Active Ribonucleic Acid from Sources Erriched in Ribonuclease, Biochem 18:5294-5299.

CHRISTOPHE, J.; CAMUS, J.; DESCHODT-LANCKMAN, M.; RATHE, J.; ROBBERECCHT, P.; VANDERMEERS-PIERET, M.C.; and VANDERMEERS, A. (1971): Factors Regulating Bio- 
synthesis, Intracellular Transport and Secretion of Amylase and Lipase in the Rat Pancreas, Horm Metab Res 3:393-403.

HAGENBUCHLE, O.; BOVEY, R.; and YOUNG, R.A. (1980): Tissue-specific Expression of Mouse Alpha-Amylase Genes: Nucleotide Sequence of Isozyme mRNAs from Pancreas and Salivary Gland, Cell 21:179-187.

HAGENBUCHLE, O.; TOSI, M.; SCHIBLER, U.; BOVEY, R.; WELLAUER, P.K.; and YOUNG, R.A. (1981): Mouse Liver and Salivary Gland $\alpha$-Amylase mRNA's Differ only in $5^{\prime}$ Non-translated Sequences, Nature 289:643-646.

HAND, A.R. and WEISS, R.E. (1984): Effects of Streptozotocin Diabetes on the Rat Parotid Gland, Lab Invest 51:429-440.

JONAS, A.M.; CRAFT, J.; BLACK, C.L.; BHATT, P.N.; and HILDING, D. (1969): Sialodacryoadenitis in the Rat. A Light and Electron Microscopic Study, Arch Pathol 88:613-622.

KIM, S.K. (1981): Age-related Changes in the Cellular Level of Amylase and Protein Synthesis in the Rat Parotid Gland, $J$ Dent Res 60:738-749.

KIM, S.K.; WEINHOLD, P.A.; HAN, S.S.; and WAGNER, D.J. (1980): Age-related Decline in Protein Synthesis in the Rat Parotid Gland, Exp Gerontol 15:71-85.

KIM, S.K; WEINHOLD, P.A.; CALKINS, D.W.; and HARTOG, V.W. (1981): Comparative Studies of the Age-related Changes in Protein Synthesis in the Rat Pancreas and Parotid Gland, Exp Ger. ontol 16:91-100.

KORC, M.; IWAMOTO, Y.; SANKARAN, H.; WILLIAMS, J.A.; and GOLDFINE, I.D. (1981a): Insulin Action in Pancreatic Acini from Streptozotocin-treated Rats. I. Stimulation of Protein Synthesis, Am J Physiol 240:G56-G62.

KORC, M.; OWERBACH, D.; QUINTO, C.; and RUTTER, W.J. (1981b): Pancreatic Islet-Acinar Cell Interaction: Amylase Messenger RNA Levels are Determined by Insulin, Science 213:351353 .

LOWRY, O.H.; ROSEBROUGH, N.J.; FARR, A.L.; and RANDALL, R.J. (1951): Protein Measurement with the Folin Phenol Reagent, J Biol Chem 193:265-275.

MANIATIS, T.; FRITSCH, E.F.; and SANIBROOK, J. (1982): Molecular Cloning, A Laboratory Manual, New York, NY: Cold Spring Harbor Lab.

McPHERSON, M.A. and HALES, C.N. (1978): Control of Amylase Biosynthesis and Release in the Parotid Gland of the Rat, Biochem $J$ 176:855-863.

OKABAYASHI, Y.; MOESSNER, J.; LOGDSON, C.D.; GOLDFINE, I.D.; and WILLIAMS, J.A. (1987): Insulin and Other Stimulants have Nonparallel Translational Effects on Protein Synthesis, Diabetes 36:1054-1060.
OSBORN, L; ROSENBERG, M.P.; KELLER, S.A.; and MEISLER, M.H. (1987): Tissue-specific and Insulin-dependent Expression of a Pancreatic Amylase Gene in Transgenic Mice, Mol Cell Biol $7: 326-334$.

OSBORN, L; ROSENBERG, M.P.; KELLER, S.A.; TING, C.-N.; and MEISLER, M.H. (1988): Insulin Response of a Hybrid Amylase/CAT Gene in Transgenic Mice, $J$ Biol Chem 263:1651916522.

PALLA, J.C.; BEN ABDELJLIL, A.; and DESNUELLE, P. (1967): Comparative Study of the Control of Amylase Biosynthesis in Rat Pancreas and Parotid Glands, Biochim Biophys Acta 136:563-565.

SCHIBLER, U.; HAGENBUCHLE, O.; WELLAUER, P.K.; and PITTET, A.C. (1983): Two Promoters of Different Strengths Control the Transcription of the Mouse Alpha-Amylase Gene Amy-1 in the Parotid Gland and the Liver, Cell 33:501-508.

SCHICK, J.; VERSPOHL, R.; KERN, H.; and SCHEELE, G. (1984a): Two Distinctive Adaptive Responses in the Synthesis of Exocrine Pancreas Results in Coordinate and Anticoordinate Regulation of Protein Synthesis, Am J Physiol 247:G611-G616.

SCHICK, J.; KERN, H.; and SCHEELE, G. (1984b): Hormonal Stimulation in the Exocrine Pancreas Results in Coordinate and Anticoordinate Regulation of Protein Synthesis, J Cell Biol 99:1569_ 1574.

SIERRA, F.; PITTET, A.; and SCHIBLER, U. (1986): Different Tissue-specific Expression of the Amylase Gene Amy-1 in Mice and Rats, Mol Cell Biol 6:4067-4076.

SNOOK, J.T. (1968): Effect of Diet, Adrenalectomy, Diabetes, and Actinomycin D on Exocrine Pancreas, Am J Physiol 215:13291333.

SÖLING, H.D. and UNGER, K.O. (1972): The Role of Insulin in the Regulation of $\alpha$-Amylase Synthesis in the Rat Pancreas, Eur $J$ Clin. Invest 2:199-212.

WIEBAUER, K.; GUMUCIO, D.L.; JONES, J.M.; CALDWELL, R.M.; HARTLE, H.T.; and MEISLER, M.H. (1985): A 78-kilobase Region of Mouse Chromosome 3 Contains Salivary and Pancreatic Amylase Genes and a Pseudogene, Proc Natl Acad Sci USA 82:5446-5449.

WILLIAMS, J.A. and GOLDFINE, I.D. (1986): The Insulin-acinar Relationship. In: The Exocrine Pancreas: Biology, Pathology, and Diseases, V.L.W. Go, Ed., New York: Raven Press, pp. $347-360$

YOUNG, R.A.; HAGENBUCHLE, O.; and SCHIBLER, U. (1981): A Single Mouse Alpha-Amylase Gene Specifies Two Different Tissue-specific mRNAs, Cell 23:451-458. 